\title{
The Relationship among Interactional Justice, Manager Trust and Teachers' Organizational Silence Behavior
}

\author{
Demet Yangin ${ }^{1}$, Cevat EIma ${ }^{2, *}$ \\ ${ }^{1}$ Ministry of National Education, Turkey \\ ${ }^{2}$ College of Education, Ondokuz Mayis University, Turkey
}

Copyright $(2017$ by authors, all rights reserved. Authors agree that this article remains permanently open access under the terms of the Creative Commons Attribution License 4.0 International License

\begin{abstract}
The purpose of this study was to determine the relationship between the manager trust and interactional justice perceptions and organizational silence behaviors of those teachers who work in primary and secondary schools. The research is based on the survey model and the population consists of 4761 teachers who worked in Samsun, Turkey. The sample of the study was chosen from 195 primary and secondary schools through a multi-stage sampling method. The study findings revealed that there exists a positive and highly significant relationship among teachers' interactional justice and their manager trust; a negative and mid-level significant relationship between their manager trust and their interactional justice; and a negative and mid-level significant relationship between their interactional justice and their manager trust, respectively. To list in order of importance, interactional justice and manager trust variables were found to be predictor variables for silence behavior and to represent $17 \%$ of change in the organizational silence behavior.
\end{abstract}

Keywords Interactional Justice, Manager Trust, Organizational Silence, Manager, Teacher

\section{Introduction}

Organizations, as communities of power and actions, which are coordinated in a planned manner to achieve their goals that stemmed from their needs but are beyond their personal capabilities $[1,2]$, have to activate resources of manpower in an efficient way. They are composed of various communities who work on a collective and sharing basis to achieve their goals. Organizations, the strength of which originates in the human capital within its own structure, feed on social components such as love, respect, commitment, understanding and communication created by human relations in order to be successful. These components are vital factors that ensure the development, improvement and survival of an organization in its own environment [3]. For this reason, determination of the effect of the concepts of trust, justice and silence, which are within the scope of this research and are highly influenced by human relations, on educational organizations may be regarded as beneficial.

The concept of trust, which has been a topic of discussion in many studies, has increasingly become a vital issue for those organizations which are in search of adapting to advancements and changes in technology $[4,5,6,7,8]$.

Organizational trust, which is a prerequisite for communication and cooperation within an organization, may be regarded as highly significant for organizational trust and the efficiency of the organization $[9,10,11,12,13]$. A high level of trust would ensure the employees and managers within an organization to do their best to fulfill their responsibilities as soon as possible. In addition, it would ensure them to be more free in sharing their ideas and more active in cooperation for achieving the organizational goals. In overall terms, those who work in environments with high levels of trust feel more comfortable when communicating their feelings, their thoughts and the differences they observe; and thereby, they increase the organizational efficiency [14, $15,16]$.

Efficiency and effective educational organizations are only possible through acting in cooperation and harmony for common purposes. This is closely related with the level of trust in educational organizations in which human relations are on the foreground $[17,18,20]$. Hence, eliminating a school atmosphere, which is devoid of trust and justice and is capable of leading to silence, is of high significance.

Justice perception, which may be regarded as an internal dimension of the research, is also influenced by organizational trust $[22,24,28,29,30]$. Several studies point out that teachers' justice perception about school managers' practices affect their level of organizational trust. For this reason, school managers are required to act fairly in order to improve organizational trust levels [23, 24].

Organizational justice is considered to be the major source of cooperative behaviors based on common activities within 
the organization. Organizational justice, which is examined as a social concept in scientific studies, is described as the employees' positive perception about managers' practices and decisions about the organization and the employees who work for it [31, 32]. Organizational justice is not only about the gains and the distribution of these gains; it also provides the basis for the rules and their implementation and the interaction between people within an organization [33]. A new brand called interactional justice was added to the concept of organizational justice, which was initially examined under two brands as distributive justice and procedural justice. These brands, which are not independent, are different in terms of their function [34].

Interactional justice, which emerges as a result of managers' treatment of their employees, focuses on interpersonal communication and behaviors during the implementation of procedures $[35,36]$. The term 'interactional justice' was first introduced by Bies and Moag [37]. The concept, which is based on the interpersonal communication within an organization and focuses on the communication between the manager and the employees, is accepted as the social dimension of organizational justice $[38,39]$. Within this context, interactional justice requires managers to treat their employees with respect, to listen to them with devotion, to make adequate explanations about their decisions, to be tolerant during hard times and to exhibit a sensitive posture in the social sense [40, 41].The more managers become respectful and kind to every employee without prejudice and the more they show that all employees are valuable during their communication, the more they will be perceived as fair [39, 42]. The explanatory dimension of interactional justice is seen as an interpersonal value of procedural justice and it may create reactions against the outcomes of decisions. For this reason, it would not be wrong to say that interactional justice affects other dimensions and it is influenced by them $[38,39]$.

It may be observed that more studies have been conducted on organizational justice and organizational trust [25, 26, 28] and on the relationship between organizational trust and organizational silence $[44,45,46,47]$ whereas a lesser number of studies deal with the relationship between organizational justice and organizational silence [48, 49]. This reveals the fact that there is a strong need to conduct more scientific studies on the reasons for organizational silence, which is influenced by the employees' trust and justice perception, and on its influences on organizations.

Silence, which is generally described as hard-to-define, hard-to-understand and hard-to-interpret by its very nature, as a concept, took its place as a term in management literature as being silent, as the absence of sound in an environment, quietness [50] and as not talking or exhibiting a kind of behavior that could be understood clearly $[51,52]$. Silence was first seen as the absence of talk or speech and it became one of the rare topics of discussion because examining the concept of silence was thought to be more difficult than examining the behaviors, which were exhibited openly, due to silence behavior's multi-dimensional drives and hardness of examining its changing structure.

The concept of organizational silence is also highly significant in educational organizations. In schools, which are established to achieve educational goals, creating a democratic and a sincere atmosphere in which teachers, who assume responsibilities feel comfortable and safe, contributes to the enhancement of performance levels. Those employees, who have a sense of belonging within their organization; who feel an internal commitment to it and accept themselves as a citizen of it, are observed to be in search of an improvement for their organization, to support it and to reflect their ideas more openly [53,54]. A decrease in the trust in and commitment to an organization leads to an interruption in the information flow within the organization and results in the silence of the employees [43,53,55,56]. In organizations where organizational silence dominates, employees do not make any intellectual contribution to the organization [57]; as a result, they have a negative effect on administrative information sharing, on the sense of responsibility for organizational problems, and on innovativeness and creativity within the organization $[58,59,60]$. This may be accepted as one of the significant indicators of the fact that organizational silence constitutes an obstacle for organizational change and development and it prevents the high levels of performance and synergy within the organization $[61,62,63,64,65]$. Within this context, managers are required to create working environments in which employees feel free to express their thoughts; an awareness of organizational learning is existent; and cooperative activities are on the foreground. Within this context, it would not be wrong to say that interactional justice would contribute to the evaluation of the influence of manager behavior types on subjects such as determination of the relationship between manager trust and organizational silence; silence, internal motivation, efficient performance and support of teachers for their organization through their thoughts, ideas and creativity.

\section{Purpose}

The purpose of this study is to determine whether there is a relationship among interactional justice, manager trust and organizational silence behaviors of those teachers who work for primary and secondary schools. To that end, the following questions guided this study:

1. Is there a relationship among interactional justice, manager trust and organizational silence behaviors of those teachers who work for primary and secondary schools?

2. Are interactional justice and manager trust behaviors of those teachers who work for primary and secondary schools significant predictor variables of organizational silence behavior? 


\section{Material and Methods}

\section{1. Research Model}

This research is designed to use a relational screening model. Screening model is an approach which covers big groups and aims to describe the thoughts, feelings, perceptions and attitudes of individuals in these groups about and towards several incidents and phenomena in their past and present conditions [66]. Through this approach, primary and secondary school teachers' interactional justice and manager trust perceptions and their organizational silence behaviors were evaluated.

\section{2. Sampling}

The universe of the study includes those teachers who work for primary and secondary schools in İlkadım, Canik, Atakum and Tekkeköy districts of Samsun during the academic year 2014-2015. A total number of 4761 teachers work for 123 primary and 72 secondary schools located in districts of Samsun, Turkey. The sample of the universe was determined through multi-stage sampling.

During the first stage, the sample was divided into four strata (İlkadım, Canik, Tekkeköy and Atakum) at district level through stratified sampling method. Stratified sampling is a sampling method which is aimed at determining and representing sub-groups in the sample with their ratio in the universe [67]. A quarter (one fourth) of the total number of public primary and secondary schools in each district is in the research sample.

During the second stage, simple random sampling model was used. In simple random sampling, it is accepted that there is an equal and independent level of possibility for all units to be chosen as a sample in the universe. Random sampling is thought to be the one which represents the universe best and the choice made through this method is regarded as the most valid and the best of all [67]. Sample size formula was used to determine the number of teachers to be used as sample within the universe. As a result of the calculations made to determine the sample size, a minimum number of 355 teachers were accepted as the required number. At the beginning of the study researchers aimed to reach more than 355 teachers; however, later in order to decrease the influence of difficulties as much as possible and to increase the validity of the sample. To that end, 730 teachers who worked for 50 randomly selected schools within the sample were handed out surveys and 625 surveys were collected and evaluated. Among those teachers who took part in the survey, more than half of them $(61,1 \%)$ were female; approximately half of them were between the ages of 31 and $40(46,7 \%)$, more than three-fourth of them $(87,5 \%)$ were married; more than half of them $(64,2 \%)$ were subject matter teachers; more than one-fourth of them $(26,1 \%)$ had 16-20 years of service as teachers; and more than half of them $(63,0 \%)$ had $1-5$ years of service in the schools they worked for, respectively.

\subsection{Data Collection Tools}

Data collection tools were divided into two sections. The first section included "Personal Information Form" which covered biographical and demographic variables concerning teachers (sex, marital status, age, seniority, years of service and district) and the second section included "Manager Trust Scale" (MTS), "Interactional Justice Scale" (IJS) and "Organizational Silence Scale" (OSS).

\subsubsection{Interactional Justice Scale}

"Interactional Justice Scale" (IJS), which was developed by Elma as a sub-dimension of organizational justice scale, was used to determine the organizational scale [68]. It included the following phrases; "My school manager considers my opinions when making a decision," "My school manager listens to my opinions when making a decision," "My school manager observes my rights as a teacher," "I believe that my school manager does his/her best for me," "My school manager explains the reasons behind his/her decisions," "My school manager is kind to me," and "My school manager trusts me". Interactional Justice Scale (IJS), which was determined as a five-point Likert scale, included the following options; "Never" (1), "Rarely" (2), "Sometimes" (3), "Mostly" (4) and "Always" (5). The highest rate was determined as "Always" and the lowest one as "Never" [68]. Cronbach's Alpha internal consistency coefficient of the scale which consisted of a total number of seven phrases was found to be .94 while factor loading values were found to vary from .41 to .76 in the consequence of factor analysis. These values show that the scale is reliable and is highly distinctive. In this study, which was conducted with 625 teachers who work for primary and secondary schools, the reliability coefficient was found as .94 .

\subsubsection{Manager Trust Scale (MTS)}

"Manager Trust Scale" (MTS), which was developed by Y1lmaz [20] and was derived from the Organizational Trust Scale with three dimensions called "Manager Trust," "Colleague Trust," and "Shareholder Trust," was used to determine the level of manager trust after obtaining the necessary permissions. The scale was accepted as a dimension of the research and it included seven items. It included the following phrases; "I trust in the school manager," "I trust in the honesty of my school manager," "The manager is interested in teachers' problems in this school," "The relationship between the manager and teachers in this school is stable," "The manager in this school is good at what he does," "The manager in this school keeps his/her promises," and "The school manager shares personal information about teachers with others" as a negative item. "Manager Trust Scale" (MTS), which was determined as a five-point Likert scale, included the following options; "Never" (1), "Rarely" (2), "Sometimes" (3), "Mostly" (4) and "Always" (5). According to the validity and reliability analyses of the scale including seven items, factor loading values of the seven items included in manager trust dimension as the first factor were found as varying from .49 
to 0.84 . The total item correlation of this factor was determined as varying from 0.52 to 0.73 ; for this reason, it is possible to claim that the items are highly distinctive. Cronbach's Alpha value of the scale was found as .89. The reliability coefficient of the scale used in this study, in which 625 teachers who worked for primary and secondary schools took part, was determined to be .91 .

\subsubsection{Organizational Silence Scale (OSS)}

"Organizational Silence Scale" (OSS), which was developed by Kahveci and Demirtaş [69] was used to determine the level of organizational silence after obtaining the necessary permissions. Organizational silence scale included eight items. According to exploratory factor analysis, the scale was composed of five factors. These factors were called (1) School Environment, (2) Feeling, (3) Source of Silence, (4) Manager and (5) Isolation. The results of the confirmative factor analysis made to determine the structure of five factors showed that first-level confirmative factor analysis result/df value is 3,07; GFI value is .912; CFI value is .920; and RMSEA value is 0,70 . Based on the values obtained, the model may claim to have convenient adaptive values. Item loadings of the scale were observed to vary from .48 to .78. Items of OSS which were prepared based on five-point likert scale were (1) "Strongly Disagree", (2) "Disagree", (3) "Somewhat disagree", (4) "Agree" and (5) "Strongly Agree". Cronbach Alpha coefficients of the scale were found to be .74 for school environment; .81 for feeling; .80 for source of silence; .79 for manager and .83 for isolation, respectively. The reliability coefficient calculated for the whole scale in general was .89. In this study, which covers 625 primary and secondary school teachers, Cronbach Alpha coefficients were determined as .71 for school environment; .74 for feeling; .75 for source of silence; .82 for manager and .87 for isolation, respectively. The reliability coefficient calculated for the whole scale in general was .90 .

\subsection{Data Analysis}

Teachers included in the sample were handed out the survey forms used for the purposes of the study. Data collection was conducted on a voluntary basis and teachers were informed of the process emphasizing that no personal phrase or information were included in the surveys. A total number of 65 surveys were analyzed.

SPSS was used for the evaluation and analysis of the findings of the study. Whether there was a relationship between interactional justice, manager trust and organizational silence, which is the first sub-problem of the study, was considered; and; if there was a relationship, Pearson product-moment correlation coefficient was considered since the variables had normal distribution during determination of the direction and the level of the relationship. In evaluating the correlation relationship between the scales, values between 0.70 and 1.00 were reflected as a high-level; values between .30 and .70 were reflected as a mid-level, and values between 0.00 and 0.30 were reflected as a low-level relationship [67]. The results were tested at $\mathrm{p}<0.01$ level.

A multiple regression analysis was made because linearity and a normal distribution were observed during the analyses made to determine the influence of interactional justice and manager trust on organizational silence, which is the second sub-problem of the study. In the study, interactional justice and manager trust were set as independent variables whereas organizational silence was set as a dependent variable. In the consequence of statistical analysis, significance level was determined as $=0.05$.

\section{Findings}

In this study, a Pearson Correlation Analysis was made to determine the relationship among interactional justice, manager trust and organizational silence behaviors based on the perceptions of primary and secondary school teachers. In addition, a multiple regression analysis was made to find the influence of interactional justice and manager trust perceptions on organizational silence levels.

Findings about the relationship among interactional justice, manager trust and organizational silence behaviors based on the perceptions of primary and secondary school teachers are presented in Table 1.

Table 1. Results of Correlation Analysis of the Relationship among Interactional Justice, Manager Trust and Organizational Silence Behaviors based on the Perceptions of Teachers

\begin{tabular}{|c|c|c|c|}
\hline & $\begin{array}{c}\text { Interactional } \\
\text { Justice }\end{array}$ & $\begin{array}{c}\text { Manager } \\
\text { Trust }\end{array}$ & $\begin{array}{c}\text { Organizational } \\
\text { Silence }\end{array}$ \\
\hline $\begin{array}{c}\text { Interactional } \\
\text { Justice }\end{array}$ & 1 & $.863^{* *}$ & $-.403^{* *}$ \\
\hline Manager Trust & $.863^{* *}$ & 1 & $-.401^{* *}$ \\
\hline $\begin{array}{c}\text { Organizational } \\
\text { Silence }\end{array}$ & $-.403^{* *}$ & $-.401^{* *}$ & 1 \\
\hline
\end{tabular}

When Table 1 is considered, based on teachers' perceptions, a positive and highly significant relationship between interactional justice and manager trust perceptions $(\mathrm{r}=.863 ; \mathrm{p}<0.01) ; \mathrm{a}$ mid-level negative significant relationship between interactional justice and organizational silence $(\mathrm{r}=-.403 ; \mathrm{p}<0.01)$; and a mid-level negative significant relationship between manager trust and organizational silence $(r=-.401 ; p<0.01)$ may be observed. These findings show that there is a direct proportion between interactional justice and manager trust perceptions whereas there is an inverse proportion interactional justice and organizational silence and manager trust and organizational silence perceptions.

A multiple regression analysis was made to determine the influence of interactional justice and manager trust perceptions on organizational silence levels and the results were examined. Findings of the regression analysis about interactional justice and manager trust behaviors' prediction of organizational silence are given in Table 2 . 
Table 2. Results of Multiple Regression Analysis about Interactional Justice and Manager Trust Behaviours' Prediction of Organizational Silence

\begin{tabular}{|c|c|c|c|c|c|c|c|}
\hline Variable & $\mathrm{B}$ & Standard Error & $\operatorname{Beta}(\beta)$ & $\mathrm{t}$ & $\mathrm{p}$ & Dual Correlation & Partial Correlation \\
\hline Invariant & 4.544 & .119 & - & 38.058 & .000 & - & - \\
\hline Interactional Justice & -.176 & .057 & -.221 & -3.068 & .002 & -.403 & -.112 \\
\hline Manager Trust & -.175 & .060 & -.210 & -2.902 & .004 & -.401 & -.116 \\
\hline $\begin{array}{c}\mathrm{R}=.416 \mathrm{R}^{2}=.173 \\
\mathrm{~F}_{(2,622)}=65.182 \mathrm{p}=.000\end{array}$ & & & & & & & \\
\hline
\end{tabular}

When Table 2 is considered, teachers' organizational silence perceptions, along with interactional justice and manager trust variables, are observed to have a mid-level significant relationship $(\mathrm{R}=.416 ; \quad \mathrm{R} 2=.173 ; \mathrm{p}<0.05)$. Interactional justice and manager trust represent approximately $17 \%$ of the total variance in organizational silence behavior. Relative order of importance of predictor variables on organizational silence in accordance with standardized regression coefficient is as follows; interactional justice $(\beta=-.221)$ and manager trust $(\beta=-.210)$. When results of t-test on the significance of regression coefficient are examined, both behaviors are seen to predict organizational silence behavior.

\section{Results and Discussion}

This study, which aims at revealing the relationship among interactional justice, manager trust and teachers' organizational silence, has the following results;

a. A high-level positive relationship between primary and secondary school teachers' interactional justice and manager trust perceptions; a mid-level negative relationship between these teachers' interactional justice perceptions and organizational silence; and a mid-level negative relationship between these teachers' manager trust perceptions and organizational silence were determined.

b. Interactional justice and manager trust perceptions were found to constitute $\% 17$ of organizational silence variance. Based on the t-test results, which reflect the significance of regression coefficient, manager trust and interactional justice variables were determined to be the significant predictor variables of organizational silence.

c. Based on the standardized regression coefficient $(\beta)$, order of significance of the predictor variables of organizational silence was found as manager trust and interactional justice, respectively.

In this study, a highly positive relationship was found between teachers' interactional justice and manager trust perceptions. Baş and Şentürk, who points out that the existence of organizational justice and organizational trust is vital [21], presents results indicating the fact that these two factors are two important components that affect teachers' attitude towards their profession, their behaviors and success in school, which is a fact demonstrating the findings of this research. Özgan, in his study [27], reveals that in an environment with a high organizational trust level, a decrease in conflicts is expected; and as a result, teachers who have positive perceptions about managers have less conflict with managers. İşçan and Sayın [25] put an emphasis on the fact that inter-organizational relationships would worsen and organizational goals would not be achieved without trust because efficient relationships are based on this feeling.

Yildiz stresses that the trust level of an individual is shaped by the manager's attitude in his/her ethical and just practices and for this reason manager trust is examined within the scope of trust which is based on interpersonal relationships [30]. Managers who exhibit behaviors affecting the manager trust perception such as honesty, interest in teachers' problems, and consistency in the relationship with teachers and keeping promises are perceived as just in their relationship with teachers. Folger and Konovsky also put an emphasis on the fact that justice of the manager not only creates respectability but also contributes to the development of trust [70].

Justice perceptions in schools affect teachers' commitment and trust towards to their managers. Moreover, justice in the gains is regarded as an indication of the fact that managers observe the rights and personal values of the employees. Celep and Polat state that school managers need to increase teachers' equality and justice perceptions through treating them with justice because managers' interactional justice perceptions increase employees' trust at a significant level [23]. It is also possible to claim that employees may have a lack of trust in their manager and they may not see themselves as a member of the organization in the absence of interactional justice, which has a significant influence on organizational justice and which is about the interpersonal relationship dimension of justice [21]. Within this context, it may be said that if teachers, opinions are listened to carefully considered in decision process and had enough respect to their opinions in the schools their trust may increase towards to their schools and managers.

Findings about the relationship between interactional justice perception and organizational silence behavior show 
that there is a negative mid-level significant relationship between interactional justice perceptions of primary and secondary school teachers and organizational silence behavior. This finding indicates that teachers' perception of managers high-level interactional justice would decrease teachers' organizational silence behavior. Indeed, it would not be wrong to say that the decrease in teachers' organizational silence behavior may change based on the increase in their perception of interactional justice of the manager. However, Taşkıran accepts interactional justice as a structure with two dimensions; that is, as distributive justice and procedural justice and he states that it has a mid-level positive relationship with organizational silence (in direct proportion/in the same direction) [49] whereas Güvenli emphasizes that interactional justice and organizational silence have a low-level non-significant relationship in reverse direction) [48]; which are both contradictory to the results of this study.

A number of studies reveal that interactional justice, which is described as justice perception emerged as a result of interpersonal relations, has a mid-level effect on reducing organizational silence behavior [38, 39, 71]. Within this context, manager behaviors such as listening to and showing respect for teachers' opinions during decision-making; choosing the best possible practices for teachers; and explaining honestly the reasons for decisions taken may contribute to reduction of teachers' silence behaviors. For this reason, it may be claimed that interactional justice, which requires managers to have respect for, to appreciate, to listen to their employees with utmost care; to make adequate explanations about decisions; to be tolerant and sensitive against their personal negative traits in social sense [40,41], is one of the important determiners of the prevention of organizational silence behavior.

Findings show that there is a negative mid-level significant relationship between interactional justice perceptions of primary and secondary school teachers and organizational silence behavior. This finding indicates that teachers' perception of manager's high-level interactional justice would decrease teachers' organizational silence behavior. Thus, it is possible to say that the decrease in teachers' organizational silence behavior may change based on the increase in their perception of interactional justice of the manager. The findings obtained from this study support the findings of the studies of Afşar (2013), Çakınberk, Dede and Yilmaz (2014) and Yanık (2012) [43, 46, 47].

This study reveals that manager trust perception, which is regarded as the most significant predictor of the concept of trust that is generally described as one of the vital functions of organizations, has a positive effect on organizational silence behavior. Creating an environment open for communication, giving a chance to actively participate in decision-making processes, and sharing important information, feelings and thoughts about the organization have an important part in establishing trust, and managers have the most significant role in attaining these objectives [3, 72]. Managers' attitude and behaviors may be thought to be highly significant for creating an environment of trust. It is also possible to say that teachers may be more cooperative, more likely to express their thoughts and feelings, if the manager is perceived as honest, if he is interested in teachers' problems, and if he acts consistently and keeps his/her promises.

Taking the results into account, it may also be said that managers' manners which give the impression that "they know best" have a negative influence on teachers and as a result this affects trust. Teachers may feel that no attention is paid to their feelings and thoughts and they may be reluctant to express their ideas. This, as a result, may lead to creation of an environment that is incompatible with management practice policies determined by modern organizations. An atmosphere of silence may prevent cooperation, team work and interaction-based practices and this may lead to environments in which teachers do not feel safe and easy about trusting their managers $[9,14,19,73,74,75]$.

Interactional justice and manager trust variables have a mid-level negative significant relationship with silence perceptions of primary and secondary school teachers. According to the findings of this study, interactional justice and manager trust represent approximately $17 \%$ of the change in organizational silence behavior. The results of t-test reflecting the significance of regression coefficient show that manager trust and interactional justice are significant predictors of organizational silence behavior. These findings support the findings of researches made by Cerit (2009), Çakınberk, Dede and Yılmaz (2014) and Yanık (2012) [45, 46, 47].

In line with the regression analysis made through teachers' opinions about organizational silence behavior, first interactional justice perceptions and then manager trust perceptions have maximal influence on reduction of organizational silence behavior, respectively. Even though there is not critical difference between these influences, findings show that first interactional justice perceptions and then manager trust perceptions need to be changed. For this reason, it may be said that, first and foremost, managers are required to be just in order to reduce silence behavior within an organization.

In recent conditions in which organizations consider and implement modern management practices, methods such as self-governing groups; popularizing democratic communication types and increasing the act of sharing are prioritized [63, 76, 77]. Communication and cooperation between the employees are attached importance during efforts to implement these practices. However, the fact that employees may be silent and indifferent to their organization also because of several negative situations and conditions is among the findings $[64,77,78]$. This study enables us to reflect some of these negative situations and conditions as manager trust and interactional justice perception. Cerit, in his study, found that manager trust has a significant role in cooperating with the manager [45]. It may be said that those teachers, who trust their manager and perceive him/her as just, are more positive and careful when expressing his/her 
shortcomings and they feel more free to reflect their feelings and thoughts. It may be said that this, in result, contributes to the removal of obstacles in emergence of new ideas and thoughts, creativity and synergy within the organization [61, $62,64]$.

The findings of this study show that only a part of silence behavior is affected by manager trust and interactional justice variables. Studies not only indicate that silence is multi-dimensional and complex [64] but also reveal that managers have significant responsibilities in controlling these variables, increasing cooperation and sharing within the organization, improving creativity and attaining goals particularly in educational organizations. It is an important fact that especially schools' managers, who are the decision-makers and the executives of educational organizations, need to observe teachers' rights; need to be more sensitive about their problems, and more successful in communication or chosen from people who are educated in this field.

\section{Recommendations}

With an end to prevent organizational silence, teachers should be encouraged to participate in decision-making processes; they should be made to feel that their ideas are important; and environments in which they could express their thoughts and ideas freely should be created. Managers should establish an open and democratic relationship with teachers and should be interested in their problems in order to integrate teachers into the school; to make them believe in the management's fairness; and to increase their organizational trust levels.

Even though there are many factors influencing teachers' organizational silence, managers' success in establishing trust-based relations and being fair would contribute to a decrease in organizational silence. Within this context, school managers should first focus on activities and behaviors that would increase teachers' trust levels and they should be fair.

A communication environment, which lacks sincerity and democracy, and which, as a result, prevents teachers from expressing their feelings and ideas, is a big obstacle for organizational development and progress. Ministry of National Education and local educational organizations should organize on-the-job training seminars that would raise awareness among managers and that would enable changes in their behaviors through improving their communication skills.

More comprehensive qualitative and quantitative researches should be conducted in order to determine the reasons for and outcomes of teachers' organizational silence in schools. The qualitative studies to be made should concentrate on manager behavior dimensions with high levels of organizational silence perception, as is also revealed in this study. Particularly interviews would be beneficial for a deep analysis on reasons for organizational silence due to the multi-dimensional, hard-to understand and hard-to-interpret nature of silence.

\section{REFERENCES}

[1] Aydın, M. (2010). Eğitim yönetimi (9.Bask1). Ankara: Hatipoğlu.

[2] Bursalığlu, Z. (2013). Okul yönetiminde yeni yap1 ve davranıs (18. Baskı). Ankara: Pegem Akademi Yayıncılık.

[3] Asunakutlu, T. (2002). Örgütsel güvenin oluşturulmasına ilişkin unsurlar ve bir değerlendirme. Muğla Üniversitesi Sosyal Bilimler Enstitüsü Dergisi, 9, 1-13.

[4] Bhattacharya, R., Devinney, T. M. \& Pillutla, M. M. (1998). A formal model of trust based on outcomes. The Academy of Management Review, 23(3), 459-472.

[5] Lewicki, R. J., McAllister, D.J. \& Bies, R.J. (1998). Trust and distrust: New relationships and realities. The Academy of Management Review, 23(3),438-458.

[6] Mishra, A. K. (1996). Organizational responses to crisis: The centrality of trust. In R. M. Kramer ve R.T. Tyler (Eds.), Trust in organizations: Frontiers of theory and research (pp.261-287) Thousand Oaks, CA: Sage Publications.

[7] Polat, S. (2009). Eğitim örgütleri için sosyal sermaye: Örgütsel güven. Ankara: Pegem Akademi.

[8] Tyler, T. R. \& Kramer, R., M. (1995). Whither trust. R. M. Kramer and T. R. Tyler (Eds), Trust in organizations frontiers of theory and research içinde (pp.1-15), Sage Publications, USA.

[9] Arslan, M. M. (2009). Teknik ve endüstri meslek lisesi öğretmenlerinin örgütsel güven algıları. Eğitimde Kuram ve Uygulama, 5(2), 274-288.

[10] Ayduğ, D. (2014). İlkokulların örgüt sağlığı ile öğretmenlerin örgütsel güven düzeyleri arasındaki ilişkilerin incelenmesi. Yayınlanmamış yüksek lisans tezi, Anadolu Üniversitesi, Eğitim Bilimleri Enstitüsü, Eskişehir.

[11] Erdem, F. (2003). Örgütsel yaşamda güven. Ferda Erdem (Ed.), Sosyal bilimlerde güven içinde (pp.153-182). Ankara: Vadi Yayınları.

[12] Hoy, W.K. \& Tschannen-Moran, M. (1999). The five faces of trust: An empirical confirmation in urban elementary schools. Journal of School Leadership, 9, 184-208.

[13] Özler, D. E., Atalay, C. G. \& Şahin, M. D. (2010). Örgütlerde sinizm güvensizlikle mi bulaşır? Organizasyon ve Yönetim Bilimleri Dergisi, 2(2), 47-57.

[14] Bökeoğlu, C.. Ö. \& Yılmaz, K. (2008). İlköğretim okullarında örgütsel güven hakkında öğretmen görüşleri. Kuram ve Uygulamada Eğitim Yönetimi, 54, 211-233.

[15] Mayer, R. C., Davis, J. H. \& Schoorman, F. D. (1995). An integrative model of organizational trust. The Academy of Management Review, 20(3), 709-734.

[16] Mishra, J. \& Morrissey, M. A. (1990). Trust in employee/employer relationships: A survey of West Michigan managers. Public Personnel Management, 19 (4), 443-443.

[17] Artuksi, E. (2009). İlköğretim okullarında görevli öğretmenlerin okulun örgütsel güven düzeyine ilişkin algıları. 
Yayınlanmış Yüksek Lisans Tezi, İnönü Üniversitesi Sosyal Bilimler Enstitüsü, Malatya.

[18] Özer, N., Demirtaş, H., Üstüner, M. \& Cömert, M. (2006). Ortaöğretim öğretmenlerinin örgütsel güven algıları. Ege Eğitim Dergisi, (7)1, 103-124.

[19] Tschannen-Moran, M. (2004). What's trust got to do with it? The role of faculty and principal trust in fostering student achievement. Paper presented at the annual meeting of the University, Council for Educational Administration, Kansas City, MO.

[20] Yılmaz, E. (2006). Okullardaki örgütsel güven düzeyinin okul yöneticilerinin etik liderlik özellikleri ve bazı değişkenler açısından incelenmesi. Yayınlanmış Doktora Tezi, Selçuk Üniversitesi, Konya.

[21] Baş, G. \& Şentürk, C. (2011). İlköğretim okulu öğretmenlerinin örgütsel adalet, örgütsel vatandaşlık ve örgütsel güven algıları. Kuram ve Uygulamada Eğitim Yönetimi, 17(1), 29-62.

[22] Brewster, C. \& Railsback, J. (2003). Building trusting relationships for school improvement: Implications for principals and teachers. Oregon, USA: Northwest Regional Educational Laboratory.

[23] Celep, C. \& Polat, S. (2008). Ortaöğretim öğretmenlerinin örgütsel adalet, örgütsel güven, örgütsel vatandaşl1k davranışlarına ilişkin algıları. Kuram ve Uygulamada Eğitim Yönetimi, 54, 307-331.

[24] Hoy, W. K. \& Tarter, C. J. (2004). Organizational justice in schools: No justice without trust. International Journal of Educational Management, 18(4), 250-259.

[25] İșcan, Ö. M. \& Sayın, U. (2010). Örgütsel adalet, iș tatmini ve örgütsel güven arasındaki ilişki. Atatürk Üniversitesi İktisadi ve İdari Bilimler Dergisi, 24(4), 195-216.

[26] Kılıçlar, A. (2011). Yöneticiye duyulan güven ile örgütsel adalet ilişkisinin öğretmenler açısından incelenmesi. İşletme Araştırmaları Dergisi, 3, 23-36.

[27] Özgan, H. (2011). Örgütsel davranış bağlamında ögretmenlerin örgütsel adalet, güven, bağl1lık, yönetici değerlendirme ve çatışma yönetimi stratejileri algıları arasındaki ilişkinin incelenmesi. Kuram ve Uygulamada Eğitim Yönetimi, 11(1), 229-247.

[28] Polat, S. (2007). Ortaöğretim öğretmenlerinin örgütsel adalet algıları, örgütsel güven düzeyleri ile örgütsel vatandaşlık davranışları arasındaki ilişki. Yayınlanmış Doktora Tezi, Kocaeli Üniversitesi, Kocaeli.

[29] Topaloğlu, I. G. (2010). İşgörenlerin adalet ve etik algıları açısından örgütsel güven ile örgütsel bağl1lık ilişkisi. Yüksek Lisans Tezi, Atılım Üniversitesi, Sosyal Bilimler Enstitüsü, Ankara.

[30] Yıldız, K. (2013). Öğretmenlerin örgütsel adalet ve örgütsel güven algıları. AİBU Sosyal Bilimler Enstitüsü Dergisi, 13(1), 289-316.

[31] Greenberg, J. (1990). Organizational justice: yesterday, today and tomorrow. Journal of Management, 16 (2), 399-432.

[32] Moorman, R. H. (1991). Relationship between organizational justice and organizational citizenship behaviors: Do fairness perceptions influence employee citizenship? Journal of Applied Psychology, 76 (6), 845-855.
[33] Özdevecioğlu, M. (2003). Algilanan örgütsel adaletin bireylerarası saldırgan davranışlar üzerindeki etkilerinin belirlenmesine yönelik bir araştırma. Erciyes Üniversitesi İktisadi ve İdari Bilimler Fakültesi Dergisi, 21, 77-96.

[34] Erdoğan, B., Kraimer, M. \& Liden, R. C. (2001). Procedural justice as a two dimensional construct: an examination in the performance appraisal context. The Journal of Applied Behavioral Science. 37 (2), 205-222.

[35] Colquitt, J. A., Greenberg, J. \& Zapata-Phelan, C. P. (2005). What is organizational justice? A historical overview of the field J. Greenberg ve J. A. Colquitt (Ed.) Handbook of Organizational Justice (pp. 3-56). Mahwah, NJ: Erlbaum.

[36] Yavuz, M. (2010). The effects of teachers' perceptions of justice and culture on organizational commitment. African Journal of Business Management, 4(5), 695- 701.

[37] Bies, R. J., \& Moag, J. F. (1986). Interactional justice: Communication criteria of fairness. Research on Negotiations in Organizations, 1, 43- 55.

[38] Akgeyik, G. (2014). Anadolu liselerinde görevli yönetici ve öğretmenlerin örgütsel adalet algısı (Diyarbakır İli Örneği). Yüksek Lisans Tezi, Dicle Üniversitesi, Eğitim Bilimleri Enstitüsü, Diyarbakır.

[39] Colquitt, J. A., Canlon, D. E., Wesson, M. J., Cristopher, O. I. H. \& Yee, K. (2001). Justice at the millennium: A meta-analytic review of 25 years of organizational justice research. Journal of Applied Psychology, 86(3), 425-445.

[40] Scarlicki, P. D. \& Folger, R. (1997). Retaliation in workplace: The roles of distributive, procedural and interactional justice. Journal of Applied Psychology, 82(3), 434-443.

[41] Thomas, P. \& Nagalingappa, G. (2012). Consequences of perceived organizational justice: An empirical study of white-collar employees. Researchers World: Journal of Arts, Science \& Commerce, 3(2), 54-63.

[42] Greenberg, J. (1993). The social side of fairness: interpersonal and informational classes of organizational justice. İn R. Cropanzano, (Editor.). Justice in the workplace: approaching fairness in human resource management (pp. 79-103).Lawrence Erlbaum Associates, Publishers, Hillsdale, New Jersey.

[43] Afşar, L. (2013). Örgütsel sessizlik ve örgütsel güven ilişkisi: Konuya ilişkin bir araştırma. Yüksek Lisans Tezi, İstanbul Üniversitesi, Sosyal Bilimler Enstitüsü, İstanbul.

[44] Atay, M. (2014). Mobbingin örgütsel güven ve örgütsel sessizliğe etkisi-bir uygulama. Yüksek lisans tezi, Kafkas Üniversitesi, Sosyal Bilimler Enstitüsü, Kars.

[45] Cerit, Y. (2009). Öğretmenlerin örgütsel güven düzeyleri ile işbirliği yapma düzeyleri arasındaki ilişki. Abant İzzet Baysal Üniversitesi Eğitim Bilimleri Dergisi, 22(2), 637-657.

[46] Çakınberk, A., Dede, N. \& Y1lmaz, G. (2014). Örgütsel güven ile örgütsel sessizlik arasındaki ilişki: bir kamu üniversitesi örneği. Journal of Economics, Finance and Accounting, 1(2), 91-105.

[47] Yanık, C. (2012). Örgütsel sessizlik ile güven arasındaki ilişki ve eğitim örgütlerinde bir araştırma. Yayınlanmıș Yüksek Lisans Tezi, Yeditepe Üniversitesi Sosyal Bilimler Enstitüsü, İstanbul.

[48] Güvenli, R. (2014). Örgütsel adalet algısı ve tükenmişlik sendromunun örgütsel sessizlik üzerindeki etkisi emniyet 
mensupları üzerinde bir araştırma. Yayımlanmamış Yüksek Lisans Tezi, Haliç Üniversitesi, Sosyal Bilimler Enstitüsü, İstanbul.

[49] Taşkıran, E. (2010). Liderlik tarzının örgütsel sessizlik üzerindeki etkisinde örgütsel adaletin rolü ve bir araştırma. Doktora Tezi, Marmara Üniversitesi Sosyal Bilimler Enstitüsü, İstanbul.

[50] TDK. (2013). Büyük Türkçe Sözlük, Türk Dil Kurumu. Kaynak: http://www.tdk.gov.tr.

[51] Dyne, L.V., Ang, S. \& Botero, I.C. (2003). Conceptualizing employee silence and employee voice as multidimensional constructs. Journal of Management Studies. 40(6), 1359-1392.

[52] Çakıcı, A. (2010). Örgütlerde iş gören sessizliği, neden sessiz kalmayı tercih ediyoruz? Ankara: Detay Yayıncılık

[53] Eroğlu, A.H., Adıgüzel, O. \& Öztürk, U.C. (2011). Sessizlik girdab1 ve bağl1lık ikilemi: işgören sessizliği ile örgütsel bağlllık ilişkisi ve bir araştırma. Süleyman Demirel Üniversitesi İktisadi ve İdari Bilimler Fakültesi Dergisi, 16, 102-103.

[54] Kolay, A. (2012). Endüstri meslek liselerinde görev yapan öğretmenlerin örgütsel sessizlik ve örgütsel bağl1l1kları arasındaki ilişki. Yayınlanmamış Yüksek Lisans Tezi, Yeditepe Üniversitesi Sosyal Bilimler Enstitüsü: İstanbul.

[55] Arlı, D. (2013). İlkokul müdürlerinin örgütsel sessizlik ile ilgili görüşleri. Trakya Üniversitesi Eğitim Bilimleri Dergisi, $3(2), 69-84$

[56] Panahi, B., Veiseh, S., Divkhar, S. \& Kamari, F. (2012). An empirical analysis on influencing factors on organizational silence and its relationship with employee's organizational commitment, Management Science Letters, 2, 735-744.

[57] Bowen, F. \& Blackmon, K. (2003). Spirals of silence: the dynamic effects of diversity on organizational voice. Journal of Management Studies, 40(6), 1393-1417.

[58] Huang, X., Van de Vliert, E. \& Van der Vegt, G. (2005). Breaking the silence culture: Stimulation of participation and employee opinion withholding cross-nationally. Management and Organization Review, 1(3), 459-482.

[59] Özdemir, L. \& Sarıoğlu Uğur, S. (2013). Çalışanların örgütsel ses ve sessizlik algılamalarının demografik nitelikler açısından değerlendirilmesi: Kamu ve özel sektörde bir araştırma. Atatürk Üniversitesi İktisadi ve İdari Bilimler Dergisi, 27(1), 257-281.

[60] Tangirala, S. \& Ramanujam, R. (2008). Employee silence on critical work 1ssues: The cross level effects of precedural justice climate, Personnel Psychology, 61, 37-68.

[61] Bayram, T. Y. (2010). Üniversitelerde örgütsel sessizlik. Yüksek Lisans Tezi, Abant İzzet Baysal Üniversitesi Sosya Bilimler Enstitüsü, Bolu.

[62] Ellis, J. B. \& Dyne, L. V. (2009). Voice and silence as observers' reactions to defensive voice: Prediction based on communication competence theory. In J. Greenberg, ve M.S. Edwards (Eds.), Voice and silence in organizations (pp. 37-61). Bingley: Emerald.
[63] Gül, H. \& Özcan, N. (2011). Mobbing ve örgütsel sessizlik arasındaki ilişkiler: karaman il özel idaresinde görgül bir çalışma. Kahramanmaraş Sütçü İmam Üniversitesi İIBF Dergisi, 2, 80-134

[64] Morrison, E. W. \& Milliken, F.J. (2000). Organizational silence: A barrier to change and development in a pluralistic world. The Academy of Management Review, 25(4), 706-725.

[65] Perlow, L. A. \& Repenning, N. P. (2009). The dynamics of silencing conflict. Research in Organizational Behavior, 29, 195-223.

[66] Karasar, N. (2012). Bilimsel araştırma yöntemi (22. Baskı). Ankara: Nobel Yayınevi.

[67] Büyüköztürk, Ş., Kılıç Çakmak E., Akgün, Ö. E., Karadeniz, Ş. \& Demirel, F. (2013). Bilimsel araştırma yöntemleri (15.Bask1). Ankara: Pegem Yayıncılık.

[68] Elma, C. (2013). The predictive value of teachers' perception of organizational justice on job satisfaction. Egitim Arastırmalar1-Eurasian Journal of Educational Research, 51, $157-176$.

[69] Kahveci, G. \& Demirtaş, Z. (2013b). Öğretmenler için örgütsel sessizlik ölçeği geliştirme çalışması. Elektronik Sosyal Bilimler Dergisi, 12(43), 167-182.

[70] Folger, R. \& Konovsky, M. K. (1989). Effects of procedural and distributive justice on reactions to pay raise decisions. Academy of Management Journal. 32 (1), 115-130.

[71] Özmen, Ö., Arbak, Y. \& Süral-Özer, P. (2007). Adalete verilen değerin adalet algıları üzerindeki etkisinin sorgulanmasına ilişkin bir araştırma. Ege Akademik Bakış. $7(1), 17-33$

[72] Tschannen-Moran, M. \& Hoy, W.K. (1998). Trust in schools: A conceptual and empirical analysis. Journal of Educational Administration, 36(4), 334-352.

[73] Bryk, A.S. \& Schneider, B. (2003). Trust in schools: A core resource for school reform. Educational Leadership, 60(6), $40-45$.

[74] Hoy, W.K., Gage, C.Q. \& Tarter, C.J. (2006). School mindfulness and faculty trust: Necessary conditions for each other? Educational Administration Quarterly, 42(2), 236-255.

[75] Hoy, W. K., Smith, P. A. \& Sweetland, S. R. (2002). The development of the organizational climate index for high schools: Its measure and relationship to faculty trust. The High School Journal, 86(2), 38-49.

[76] Kahveci, G. \& Demirtaş, Z. (2013a). Okul yöneticisi ve öğretmenlerin örgütsel sessizlik algıları. Eğitim ve Bilim, 38(167), 50-64.

[77] Ruçlar, K. (2013). Örgüt kültürü ve örgütsel sessizlik arasındaki ilişki-Sakarya ili örneği. Yayımlanmamış Yüksek Lisans Tezi, Sakarya üniversitesi Eğitim Bilimleri Enstitüsü, Sakarya.

[78] Edmonson, A.C. (2003). Speaking up in the operating room: how team leaders promote learning in interdisciplinary action teams. Journal of Management Studies. 40(6), 1419 - 1452. 